\title{
IMPACT DEFLECTOMETRY IN THE STRUCTURAL EVALUATION, CENTRAL HIGHWAY KM $12+250$ - KM 26 + 500, LIMA 2020
}

Carlos Abner Julca Vásquez

Graduate University School - EUPG - Federico Villarreal National University, (Perú). E-mail: carlos.julcav@gmail.com ORCID: https://orcid.org/0000-0002-2817-9079

Vicenta Tafur Anzualdo

Graduate University School - EUPG - Federico Villarreal National University, (Perú). E-mail: itafur@unfv.edu.pe ORCID: https://orcid.org/0000-0002-1888-7848

Doris Esenarro

Graduate University School - EUPG - Federico Villarreal National University, (Perú). E-mail: desenarro@unfv.edu.pe ORCID: https://orcid.org/0000-0002-7186-9614

\section{Citación sugerida:}

Julca, C. A., Tafur, V., y Esenarro, D. (2021). Impact deflectometry in the structural evaluation, Central Highway km $12+250$ - km 26 + 500, Lima 2020. 3C Tecnología. Glosas de innovación aplicadas a la pyme, 10(2), 95-115. https://doi. org/10.17993/3ctecno/2021.v10n2e38.95-115 


\section{ABSTRACT}

This research analyzes the incidence and efficiency of impact deflectometry to evaluate and design the road reinforcements of a section of the central highway. For this study, a "non-destructive" methodology has been used, based on the collection, processing, and interpretation of the deflections measured on the road surface with the impact deflectometer equipment; these deflections reflect a response of the structural package under a given load, its measurement is simple, fast and "non-destructive," that is, we do not alter the structural package, and above all, we do not cause vehicular congestion as it would be with the conventional methodology. The deflections are analyzed using the back-calculation technique, which allows us to know the total Structural Number in the function of the characteristics of rigid pavement, obtaining a structural number Sn of 6.2 and 5.6 for the right and left the roadway, respectively. This research presents the results of the current condition of the road under study. It proposes a technique for calculating the Structural Number of an asphalt reinforcement on concrete from the back-calculation.

\section{KEYWORDS}

Deflection, Deflectometry, Non-Destructive, Structural Package, Structural Number, Reinforcement. 


\section{INTRODUCTION}

Within the international context of the standards applied for the analysis and evaluation required to determine the structural condition of road pavement, applying the so-called destructive and nondestructive methods or tests stands out.

It is considered that measuring the condition of an existing pavement requires the application of destructive processes on the road, which altered the balance of the pavement-subgrade system. However, through new technologies or state-of-the-art instruments that apply high-performance testing techniques, known as Non-Destructive Testing (NDT), roadway monitoring has improved (Alderete \& Brizuela, 2014). Among these techniques, the use of the Falling Weight Deflectometer (FWD), whose function is to analyze the structural condition of pavements by interpreting the deflections produced under dynamic loads that simulate the effect of traffic, stands out. Another characteristic of the nondestructive evaluation methodology is that since the "test sample" is the pavement itself, it represents the true reflection of the complex interaction between its components (layers of materials and subgrade), and this "sample" can be tested at any time during its life without disturbing or destroying it.

The use of the impact deflectometer generates a deflection basin which represents the response of the structural package due to the application of a load which is produced by vehicular traffic so that the deflection can be correlated with the structural capacity of pavement so that if the deflection is high in a structural model, the structural power of the pavement model is weak or deficient. Conversely, if the deflection is low, it means that the structural model of the pavement has good structural capacity. With the help of back-calculation, it is possible to determine the pavement modulus used to calculate the pavement's structural capacity (Andrade et al., 2015). Therefore, the back-calculation methodology (also called retro analysis) is a tool that is currently considered the most appropriate for the structural evaluation of pavements, which allows the determination of the modulus of the layers that compose it and of the subgrade based on the knowledge of the thicknesses and the initial modulus. 
Currently, in Peru, the alternative of evaluating the structural capacity utilizing the study of deflections in concrete and asphalt pavement using the impact deflectometer is little known.

\subsection{LITERATURE REVIEW}

\section{Impact Deflectometry}

Impact Deflectometry is a technology that allows evaluating the in-situ resilient modulus of pavement and its component layers. This information is obtained by applying a dynamic load to the coating to assess and record its deformation through sensors.

\section{Impact Deflectometer}

The impact deflectometer generates a deflection basin. The characterization of the basin determines a series of parameters that allow calculating the capacity of the subgrade of a pavement structure. Impact tests are widely used to determine the subgrade strength with the Falling Weight Deflectometer (FWD); since they are non-destructive, they are a precious and fast technology, which, when adequately applied, provides a wealth of information at a very reasonable cost and time.

It is provided with a variable number of geophones located at different distances from the load application point, allowing for the deflection basin. Due to its characteristics are used in the non-destructive structural evaluation of already paved roads, generally when analyzing their rehabilitation requirements with reinforcement layers. This use justifies its high value since with an FWD, measurements can be made continuously along several kilometers per day, being constantly moved to different sections under analysis (Smith et al., 2017).

\section{Structural Evaluation}

The structural evaluation of pavements consists of determining the bearing capacity of the pavementsubgrade system in an existing road structure. The back-calculation methodology (also called retro- 
analysis) is a tool that is currently considered the most appropriate for the structural evaluation of pavements (Ávila et al., 2015).

\section{METHOD}

\subsection{SITE ANALYSIS}

The investigation was carried out on Route PE-22 - Emp. Lima - Chosica (Ricardo Palma Bridge) Matucana - Morococha, located between kilometers 12+250 to 26+500, where Santa Clara - Chaclacayo is located.

It has a total length of $28.50 \mathrm{~km}$ as the section under study is made up of two carriageways, and each carriageway has 2 to 3 lanes.

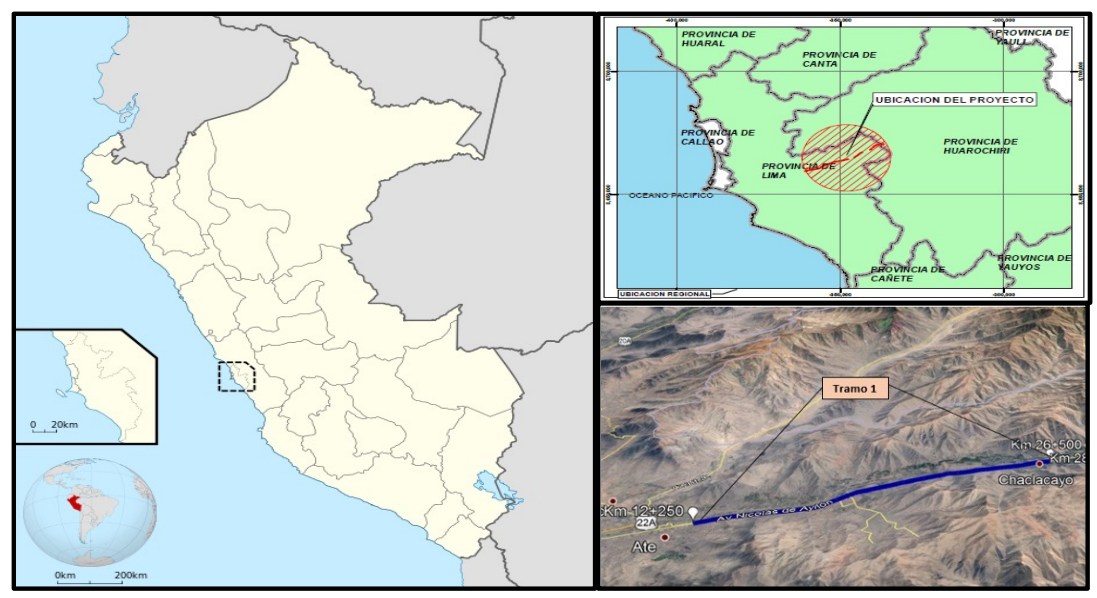

Figure 1. Geographical location of the section under study.

Source: own elaboration. 
Figure 1 shows the specific location of the section of the central highway under study, where the starting point km 12+250 with coordinates (294768; 8671131) at an altitude of 417 masl and the endpoint at km 26+500 with coordinates $(308077$; 8675700) at the height of 671 masl (Hoffman \& Thompson, 1981).

\subsection{CHARACTERISTICS OF THE STUDY AREA}

\section{Glimate and Meteorology}

The climate is warm and temperate between Santa Clara and Chaclacayo with an average of $26.7^{\circ} \mathrm{C}$, January is the warmest month, and the lowest average temperatures of the year occur in June when it is around $17.5^{\circ} \mathrm{C}$. The climate in the area is hot and temperate. They have a significant amount of rainfall during the year, with averages of $1364 \mathrm{~mm}$ (Méndez et al., 2020).

\subsection{MATERIALS}

The evaluation of asphalt reinforcement on flexible pavements using the FWD follows a methodology proposed in the AASHTO 93 guide. Still, the mounts on a mixed pavement (concrete slab with asphalt overlay) as is the case of the Central Highway from $\mathrm{km} 12+250$ to $\mathrm{km} 26+500$ would not be possible to apply directly due to the type of rigid structure, so a methodology is proposed to determine the Structural Number from the back-calculation parameters for the model of a rigid pavement (King \& Roesler, 2014).

For calculating concrete slabs, Hoffman and Thompson (1981) developed a method to transform the deflection data obtained from FWD tests of flexible pavement into a deflection basin area known as AREA (1). This term, defined as AREA36, is calculated from normalized surface deflections measured 0-in. (d0), 12-in. (d12), 24-in. (d24), and 36-in. (d36) offset from the center of the loaded plate (0, 30.5, 61.0 and $91.4 \mathrm{~cm}$, respectively) (Alderete \& Brizuela, 2014). 


\section{FWD Impact Deflectometer}

The equipment used for the measurement of deflections in the asphalt binder sections was the FWD KUAB 150 impact deflectometer (Figure 2), a dynamically loaded device coupled to a trailer, which is transported by a van that meets all the requirements standardized by ASTM D 4694-96 and the SHRP calibration protocol for this type of equipment. The deflections produced are measured by a group of seven (7) seismometers spaced every $0.30 \mathrm{~m}$, allowing to obtain the complete curve of the deflection basin (William, 2014).

The results obtained for the deflections are reported in the corresponding annex, where the deflections measured by the group of seismometers which are located at distances of $0,0.30,0.60,0.90,1.20,1.50$, and $1.80 \mathrm{~m}$ from the center of the load disk are recorded; the temperature and the impact application load are also shown.

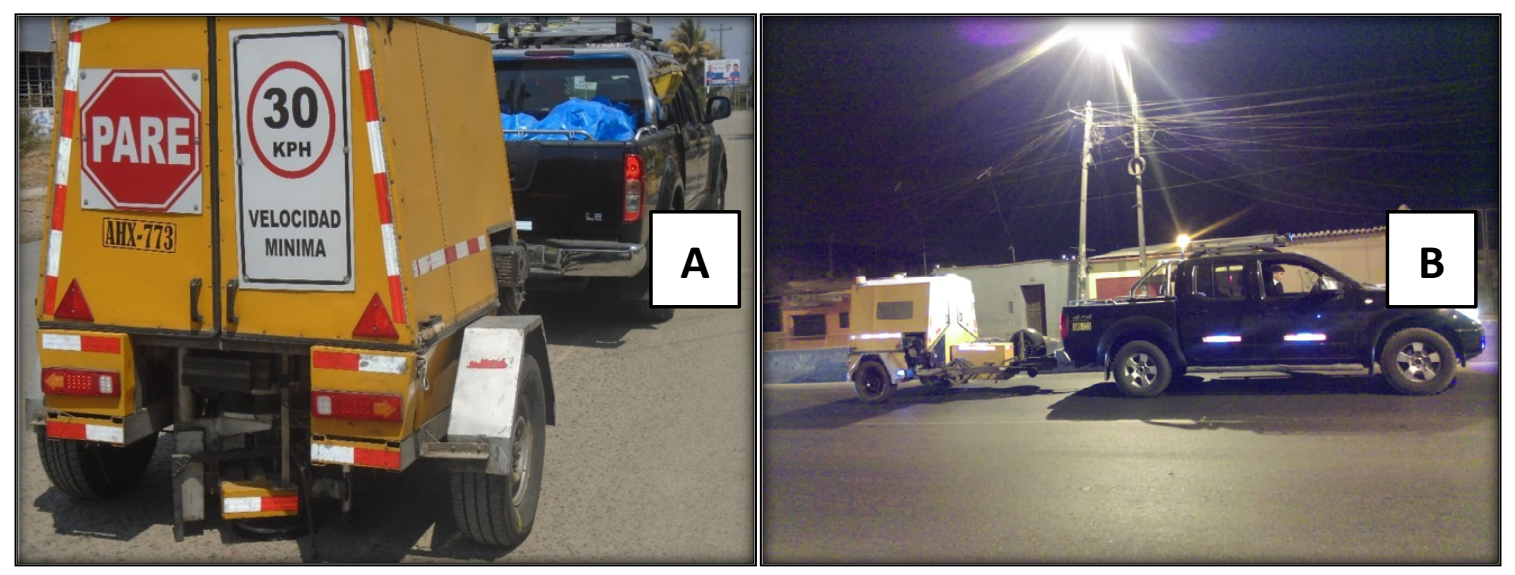

Figure 2. Impact deflectometer KUAB - 150 coupled to a trailer transported by a pickup truck, this device is dynamically loaded and meets ASTM D 4694-96 requirements.

Source: own elaboration. 


\section{FWD Measurement Procedure}

The measurement of deflections in the pavement structure was performed on May 6 to 10, 2019, alternately on the right and left lane of the roadway, every two hundred meters lane, equivalent to one hundred meters roadway ten (10) points per kilometer (Ávila et al., 2020).

The test was carried out by applying a load of approximately $50 \mathrm{KN}$ on the pavement; three (3) blows or measurements were made at each measurement point to ensure the repeatability of the results within an acceptable deviation range. The distance traveled by the equipment is registered by an odometer that indicates the location of the point to be measured. The FWD has an infrared thermometer that automatically registers the pavement surface temperature at each measurement point (Ministerio de Transportes y Comunicaciones, 2013).
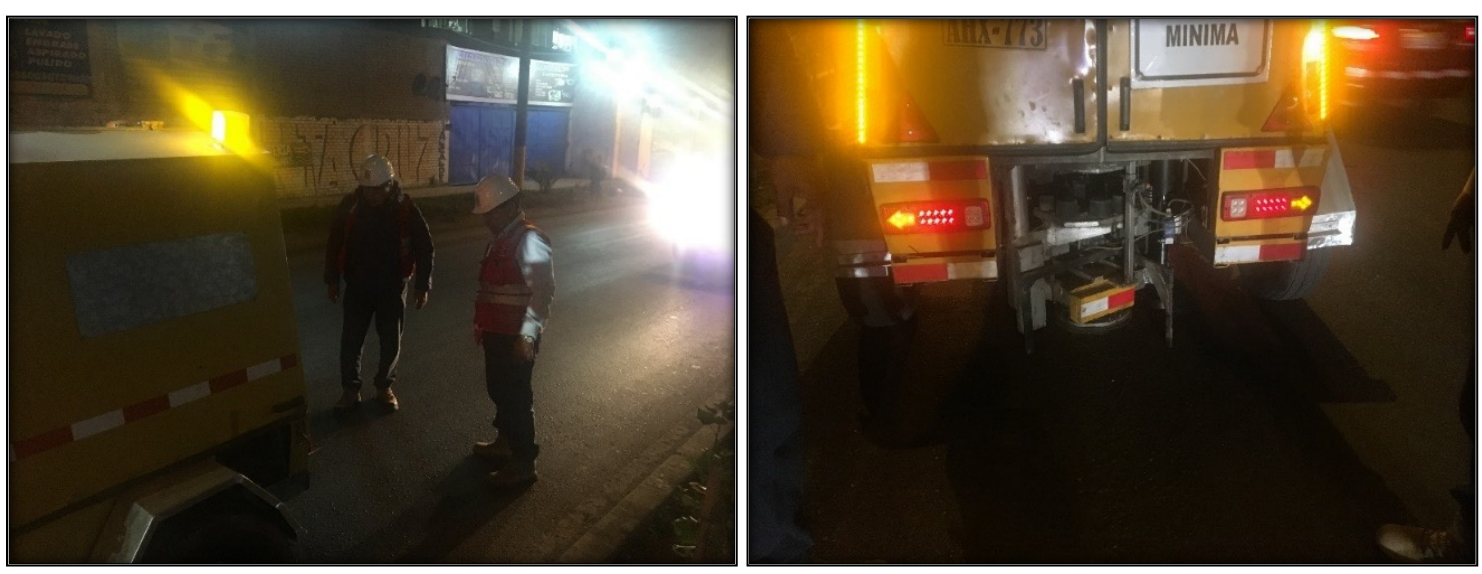

Figure 3. Inspection data collection.

Source: own elaboration.

Figure 3 shows the personnel in charge of data collection with the Impact Deflectometer KUAB 150; once the reading is done, the FWD equipment advances to its next data collection point. 


\section{Structural Parameters}

The structural capacity of a typical rigid pavement (without load transfer bars) and without other additional layers is mainly given by the slab thickness (D), the Elastic Modulus of Concrete (EC), and the Modulus of Subgrade Reaction (k). To know the thickness of the asphalt overlay, the slab thickness has been cored, and therefore retro analysis allows determining EC and k from the FWD measurements. Retroanalysis in rigid pavements is based on obtaining two basic parameters of the deflection basin (Figure 3): maximum deflection and basin area.

\section{Figure 5. Deflection Basin.}

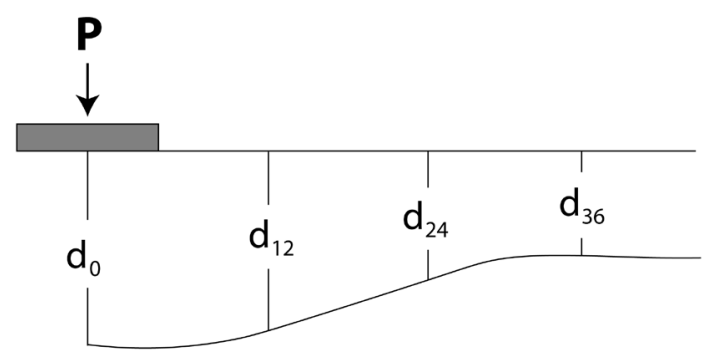

\section{Source: own elaboration.}

- Maximum deflection: Corresponds to the deflection measured by the sensor located under the load plate $(\mathrm{d} 0)$

- AREA: It is an indicator that considers the shape of the basin when incorporating more distant deflections, and in the case of rigid pavements, it is calculated as:

$$
A R E A(\text { pulg. })=6 *\left[1+2 \frac{d_{12}}{d_{0}}+2 \frac{d_{24}}{d_{0}}+2 \frac{d_{36}}{d_{0}}\right]
$$

Where:

$\mathrm{d}_{0}=$ Maximum deflection under load plate

$\mathrm{d}_{12}, \mathrm{~d}_{24}, \mathrm{~d}_{36}=$ Deflection at 12,24 and 36 inches from load plate 
On the other hand, both EG and $\mathrm{k}$ are related to each other according to the elastic theory developed by Westergard in rigid pavements (Westergard, 1939) using a parameter called relative stiffness (Lk) according to the following relationship:

$$
l_{k}=\sqrt[4]{\frac{E_{c} D^{3}}{12\left(1-u^{2}\right) k}}
$$

For the development of retro analysis in rigid pavements, it was determined that there is a relationship between the relative stiffness (Lk) and the AREA parameter:

$$
l_{k}(p u l g)=\left[\frac{\ln \left[\frac{36-A R E A}{1812,279133}\right]}{-2,559340}\right]^{4,387009}
$$

Once determined (Lk), the value of $\mathrm{k}$ can be obtained according to the deflection equation developed by Westergard for rigid pavements:

$$
\mathrm{K}=\left(\frac{P}{8 \mathrm{~d}_{0} l_{k}^{2}}\right)\left(1+\left(\frac{1}{2 \pi}\right) *\left\lfloor\operatorname{In}\left(\frac{a}{2 l k}\right)+y-1,25\right\rfloor\left(\frac{a}{l k}\right)^{2}\right)
$$

Where:

P: Load in pounds

a: Load plate radius, inches

Ү: Euler's constant, 0.57721566490

Finally, with the values of $1 \mathrm{~K}$ and $\mathrm{k}$, the modulus of elasticity Ec of the concrete pavement can be cleared from relation (2) (Hoffman \& Thompson, 1981).

In case the model is used to evaluate asphalt overlays on concrete pavements, AASHTO considers that the original deflection basin must be corrected in its maximum deflection due to the local compression 
effect that occurs in the asphalt layer when it is supported on a rigid layer (d0compress) according to the following relation for bonded overlays:

$$
\text { d0compress }=-0.0000328+121,5006\left[\frac{D a c}{E a c}\right]^{1,0798}
$$

Where:

Dac: Thickness of asphalt overlay, in.

Eac: modulus of elasticity of asphalt concrete, psi

The elastic modulus is determined as a function of temperature according to the following simplified relationship proposed in AASHTO for the particular loading frequency conditions of FWD from a more general relationship developed by Witczak for the Asphalt Institute.

$$
\log \mathrm{E}_{a c}=6.451237-0.000164671 . \quad t_{p}^{1.92544}
$$

Where:

Tp: Floor temperature, ${ }^{\circ} \mathrm{F}$

Once the maximum deflection has been corrected for the effect of localized compression, the ratios developed by AASHTO for retro analysis in rigid pavements can be applied directly (Ubalde et al., 2020).

\section{RESULTS}

\subsection{HOMOGENEOUS SECTORS}

To establish working sectors with similar behavior and characteristics that facilitate the determination of the design parameters per section in the road section, the cumulative difference analysis method was used. 


$$
F=\frac{A t}{L}
$$

Where:

At: Sum of the cumulative area values obtained.

L: Length of the section under study $(\mathrm{km})$

\subsection{DEFLEXION CHARACTERISTICS}

After finding the homogeneous sectors and according to the road type classification, which refers to Table 12. 22 of the Roads Manual, Soils and Pavements section of the MTC, the characteristic deflection is calculated using the statistical factor 1.645 at reliability of $95 \%$ corresponding to the first-class roads.

$$
D c=D m+1.645 * d s
$$

Where:

Dc: Characteristic Deflection.

Dm: Mean Deflection.

ds: Standard Deviation 


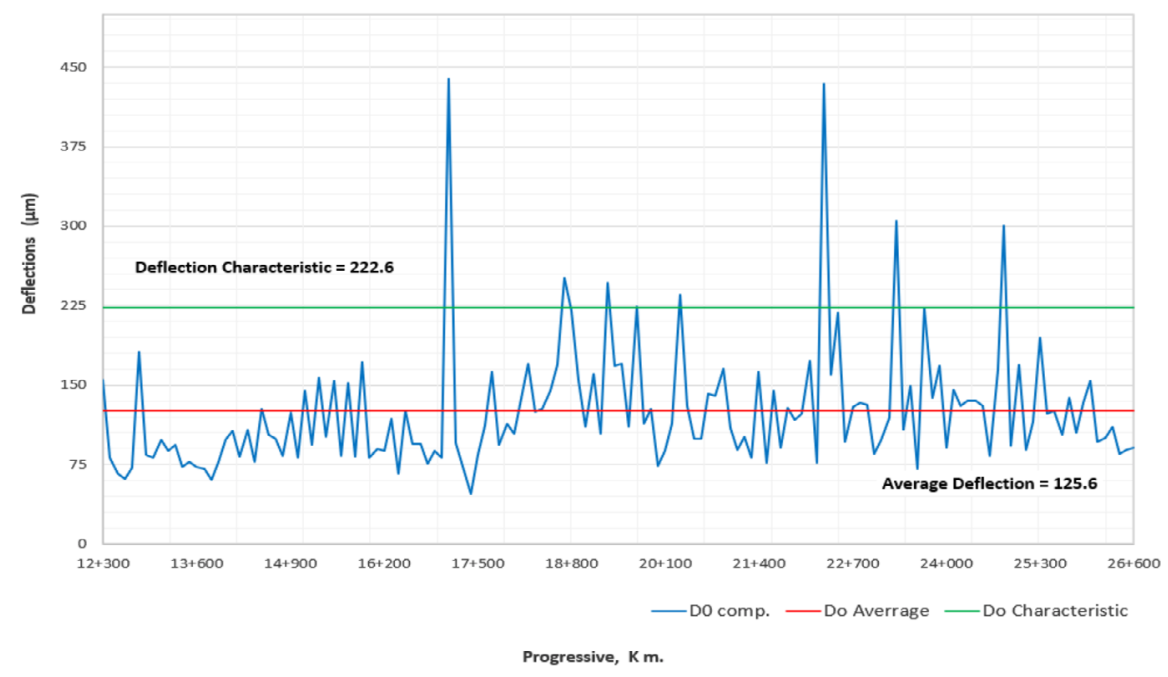

Figure 4. Calculation of deflections CZD.

\section{Source: own elaboration}

Figure 4 and Figure 5 show the deflection readings of the right and left the roadway, respectively. The calculation of the average deflection Do and the characteristic deflection Dc, calculated by equation (8) (right road $=222.6$, left road $=353.9$ ), is a fundamental parameter in the structural evaluation of pavements (Esenarro et al., 2021). 


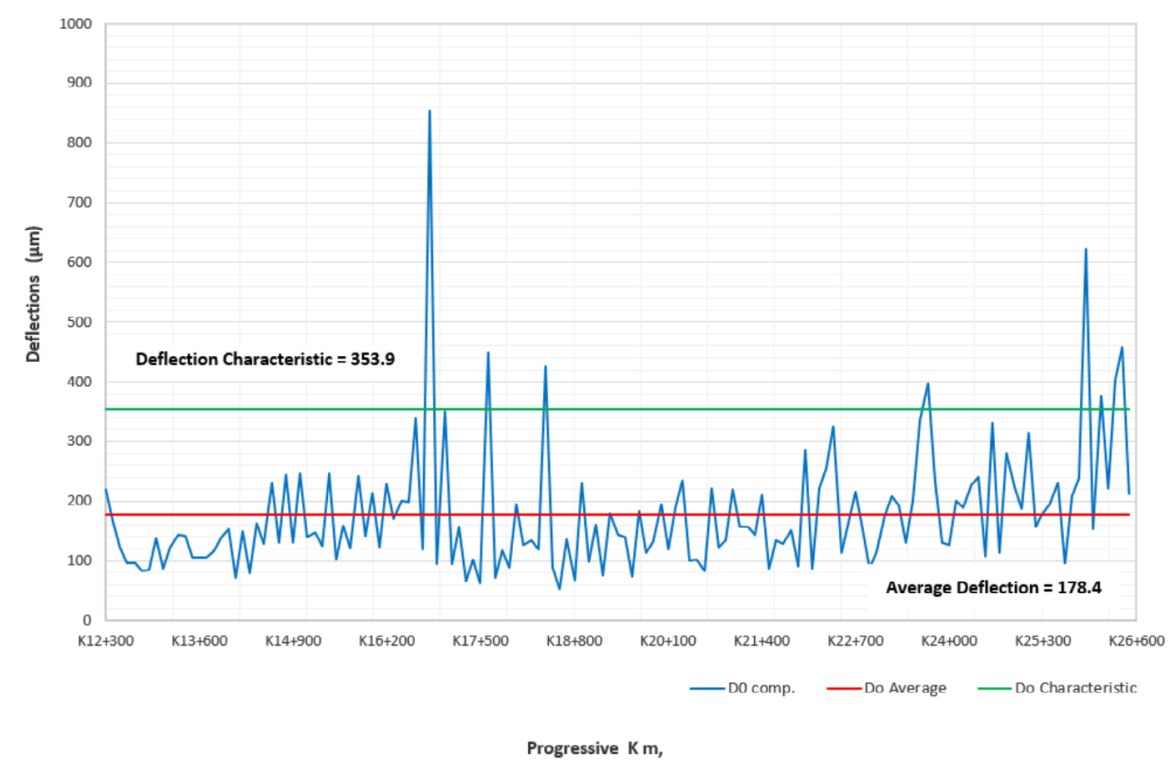

Figure 5. Calculation of deflections CZI.

Source: own elaboration.

\subsection{ESTIMATE OF THE STRUCTURAL NUMBER}

In the present investigation, the maximum deflection must be corrected because we are dealing with asphalt overlays on a mixed pavement (concrete slab with asphalt overlay). Once the maximum deflection is fixed for the effect of localized compression using the equation, the relationships developed by AASHTO for retro analysis in rigid pavements can be applied directly. Obtaining the bowl area from the deflection area as a function of the maximum deflection and the deflections at 12, 24, and 36 in. we calculate the relative stiffness using equations ( 1 and 3). We obtain the effective Modulus $\mathrm{K}$ using equation (4) with the calculated area and relative stiffness (Hoffman \& Thompson, 1981). 
For the calculation of the Effective Structural Number (SN), we use back-calculation parameters with the following expression:

$$
S N=\frac{2747.5}{d_{0}^{0.40647786} \cdot K^{0.19848453}}
$$

Where:

SN: Effective Structural Number.

$\mathrm{d}_{0}$ : Deflection at Center, in $\mathrm{mm}$

$\mathrm{K}$ : Modulus of reaction of the subgrade, in $\mathrm{Mpa}$

Now the modulus of subgrade reaction according to Hogg's model for a mixed pavement is calculated with the following equation:

$$
K 1.17+63 \sqrt{R}
$$

Where:

$\mathrm{K}$ : Modulus of subgrade reaction, in Mpa.

R: Resistance value Hvenn (R-value of the subgrade)

To determine the Hvenn resistance value, the method relies on the following expression developed by the Washington Department of Transportation.

$$
R 1.17+63 \sqrt{R}
$$

Where:

R: Hvenn's Resistance Value of the Subgrade.

Mr: Resilient modulus of the subgrade, in KSI 


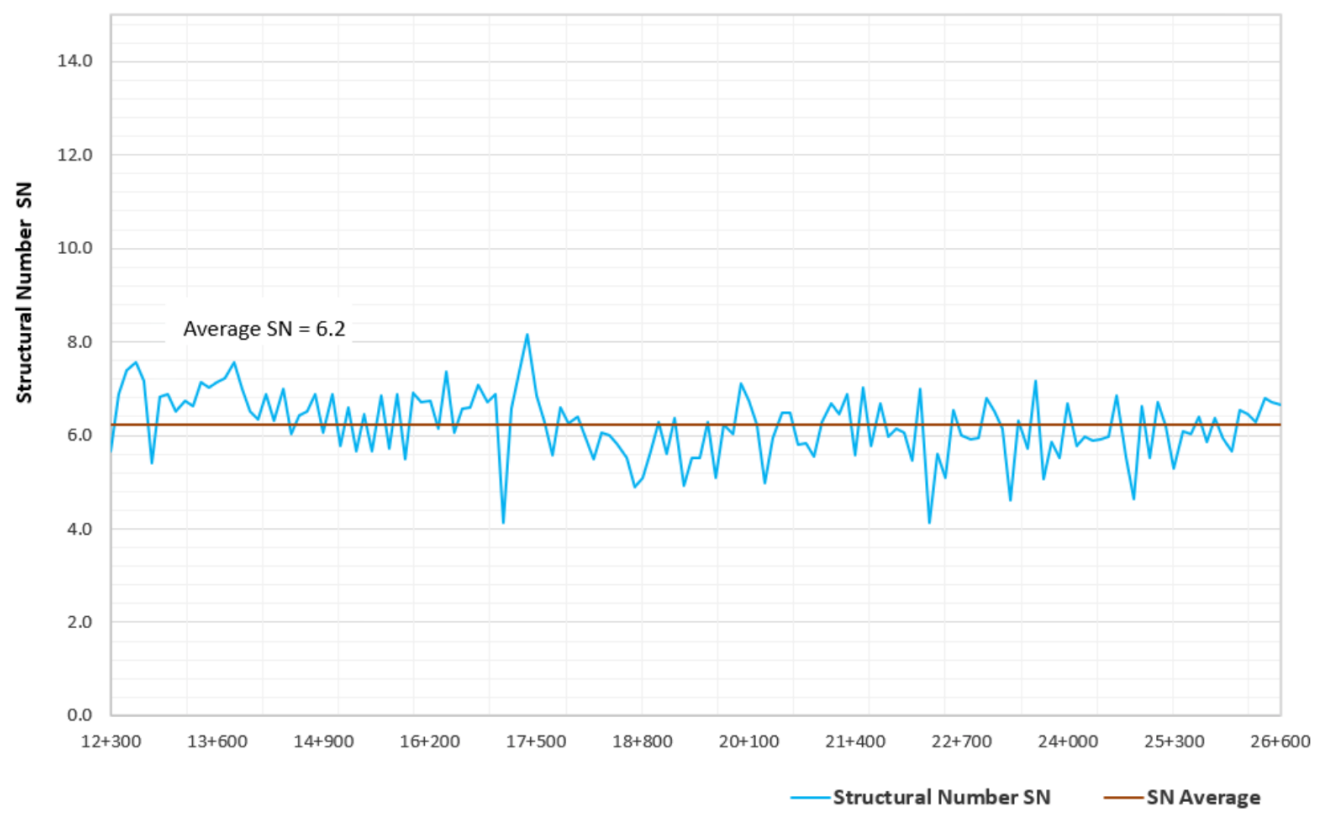

Figure 6. CZD Structural Number.

Progressive $\mathrm{K} \mathrm{m}$,

\section{Source: own elaboration}

Figure 6 and Figure 7 show the calculation of the Structural Number for the right and left the roadway, respectively, using equations $(9,10$, and 11) where the average $\mathrm{SN}=6.2$ for the proper street and $\mathrm{SN}=$ 5.6 for the left road are also observed (Smith et al., 2017). 


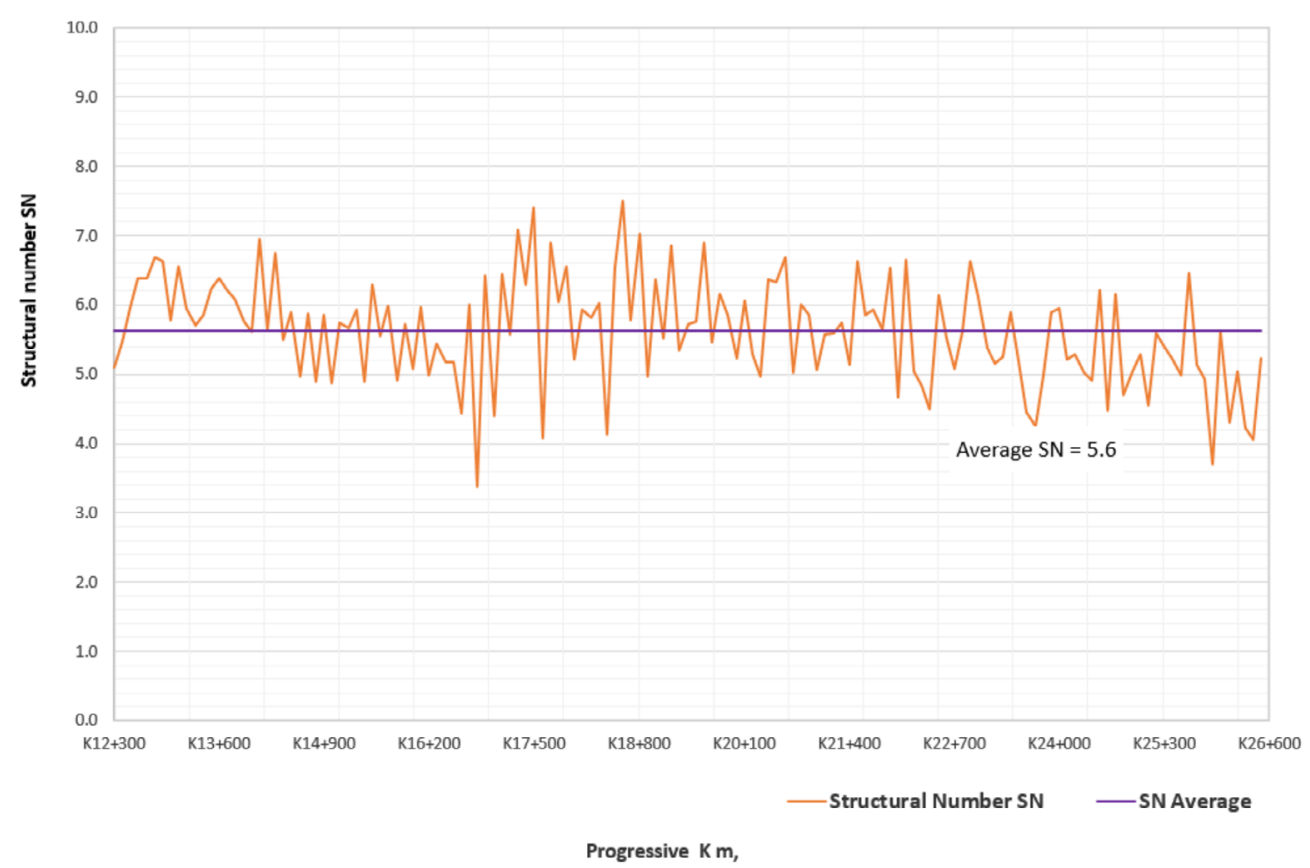

Figure 7. CZI Structural Number.

Source: own elaboration

Table 1. Structural parameters.

\begin{tabular}{|c|c|c|c|c|c|c|c|}
\hline SECTION & ROADWAY & $\begin{array}{c}\text { CONCRETE } \\
\text { SLAB } \\
\text { THICKNESS }\end{array}$ & $\begin{array}{c}\text { ASPHALT } \\
\text { LAYER } \\
\text { THICKNESS }\end{array}$ & EAC & $\mathbf{k}$ static & $\begin{array}{c}\text { MODULUS } \\
\text { OF } \\
\text { ELASTICITY } \\
\text { Ec }\end{array}$ & $\begin{array}{c}\text { STRUCTURAL } \\
\text { NUMBER }\end{array}$ \\
\hline $\mathbf{k m ~ 1 2 + 2 5 0}$ & Right & $\mathbf{( c m )}$ & $\mathbf{( p u l g )}$ & $\mathbf{( p s i )}$ & $\mathbf{( p c i )}$ & $\mathbf{( p s i )}$ & $\mathbf{S N}$ \\
$\mathbf{k}$ & 26.2 & 3.7 & $661,061.2$ & 241.6 & $33,701.3$ & 6.2 \\
\hline
\end{tabular}

Source: own elaboration 
Table 1 shows the average thicknesses of the asphalt overlay and the existing concrete slab. These were obtained by taking core samples and calculating the structural parameters of the modulus of elasticity of the asphalt and concrete, static K-modulus, and the structural number (Andrade et al., 2015).

\section{CONCLUSIONS}

The test was performed by applying a load of approximately $50 \mathrm{KN}$, generating three (3) blows in each of the test points to know the behavior of the evaluated structure. The spacing between tests is $100 \mathrm{~m}$.

To determine the thicknesses of the existing structural package (asphalt coating and concrete slab), core samples were extracted.

The Structural Number obtained for the proper roadway is $\mathrm{SN}=6.2$ and for the left road is $\mathrm{SN}=5.6$.

With the information of the deflection basin obtained with the impact deflectometer, the structural capacity of pavement in service can be calculated by means of the parameter called Structural Number Sn.

The application of this methodology significantly facilitates the controls and the structural evaluation of the road reinforcements on mixed pavements with significant advantages:

- No destructive evaluations.

- Reduction of time and efficient procedures to know the road reinforcement of a road.

\section{REFERENCES}

Alderete, N., \& Brizuela, L. (2014). Diseño de pavimentos urbanos por retrocalculo según guía AASHTO 93 mediante la utilización del deflectómetro liviano de impacto. Infraestructura Vial, 16(27), 4-14. https://dialnet.unirioja.es/servlet/articulo?codigo $=5051931$ 
Andrade Neto, I. G., Andrade Neto, D. I. I., \& Rufino, D. I. J. (2015). Metodología de análisis de la condición del pavimento a partir del cuenco de deflexión. Infraestructura Vial, 17(29), 24-32. https://doi.org/10.15517/iv.v17i29.15270

Ávila, E., Albarracín, F., \& Bojorque, J. (2015). Evaluación de pavimentos en base a métodos no destructivos y análisis inverso. Maskana, 6(1), 149-167. https://doi.org/10.18537/mskn.06.01.11

Avila, L. A., Esenarro, D., Rodriguez, C., Paredes, P., \& Metzger, L. (2020) Application of Pavement Index for the Evaluation of the Running Surface of the Lima-Peru Roads. Fournal of Green Engineering, 10(10), 8129-8141. https://siis.unmsm.edu.pe/es/publications/application-ofpavement-index-for-the-evaluation-of-the-running-s

Esenarro, D., Martinez, R., Miranda, M., Begazo, L., \& Segovia, E. (2021). Sustainable Construction of Ancasmarka and Its Functionality in the Pre-Inca and Inca Period, Calca - Cusco - Perú. Fournal of Green Engineering (fGE), 11(2). http://www.jgenng:com/volume 1 1-issue2.php

Hoffman, M. S., \& Thompson, M. R. (1981). Mechanistic Interpretation of Nondestructive Pavement Testing Deflections. UILU-ENG-81-2010. University of Illinois at Urbana-Champaign. https://trid.trb. $\mathrm{org} /$ view/169968

King, D., \& Roesler, J. R. (2014). Backcalculation procedure for bonded concrete overlays of asphalt pavement. Transportation Research Record, 2457(2), 72-79. https://doi.org/10.3141/2457-08

Martínez, W., \& Moyano, G. A. (2014). Evaluación Estructural Del Pavimento En Las Plataformas Norte $Y$ Sur Del Aeropuerto Internacional El Dorado. Universidad Católica de Colombia. https://repository. ucatolica.edu.co/bitstream/10983/2571/1/Evaluaci\%C3\%B3n-estructural-pavimentoplataformas-norte-y-sur-El-Dorado.pdf 
Méndez, R., Esenarro, D., Amaya, P., \& Rodriguez, C. (2020). Vulnerability of the soils of Metropolitan Lima and their relationship with urban sustainability. 3C Tecnología. Glosas de innovación aplicadas a la pyme. Edición Especial, Octubre 2020, 161-177. https://doi.org/10.17993/3ctecno.2020. specialissue6.137-147

Ministerio de Transportes y Comunicaciones. (2013). Manual de Carreteras- "Especificaciones Técnicas Generales para la Construcción". Lima.

Smith, K. D., Bruinsma, J. E., Wade, M. J., Ghatti, K., Vandenbossche, J. M., \& Yu, H. T. (2017). Using Falling Weight Deflectometer Data with Mechanistic-Empirical Design and Analysis, Volume I: Final Report. Report No. FHWA-HRT-16-009. Federal Highway Administration, I(March), Report No. FHWA-HRT-16-009. https://www.fhwa.dot.gov/publications/research/infrastructure/ pavements/16009/16009.pdf

Ubalde, R., Rodriguez, G., Petrlik, I., Esenarro, D., Lezama, P., \& Sotomayor,J. (2020). Quality model for Peruvian microenterprises of a software product Factory. Test Engineering and Management, 83, 13434. 
